\title{
Review of the state anti-corruption institutions effectiveness in Ukraine
}

\section{Огляд ефективності державних антикорупційних інституцій в Україні}

Received: February 25, 2021

\begin{abstract}
The objective of the article is a review of the state anti-corruption institutions' effectiveness in Ukraine. An important part of anti-corruption reform in Ukraine has been the complete transformation of anti-corruption institutions.

That is why the authors try to use the most optimal methodology that would be able to ensure the comprehensiveness and completeness of the study: phenomenological; the descriptive; the hypothetic-deductive; the statistical; and the method of case law analysis.

It is proposed to analyze the anti-corruption powers of general competence authorities in the sphere of anti-corruption. The authors analyzed the powers of specialized anti-corruption authorities' functioning: the National Agency on Corruption Prevention; the National AntiCorruption Bureau; the National Agency for finding, tracing, and management of assets derived from corruption and other crimes; the Specialized Anti-Corruption Prosecutor's Office and the High Anti-Corruption Court.

The conclusion is drawn that, realizing the need of the anti-corruption task, the state has developed an extensive and relatively closed system of specialized anti-corruption authorities. Almost all bodies of state power and local selfgovernment have acquired certain anticorruption competencies. The authors made
\end{abstract}

Accepted: March 30, 2021

\author{
Written by: \\ Olha Bondarenko ${ }^{80}$ \\ https://orcid.org/0000-0002-2288-1393 \\ Maryna Utkina ${ }^{81}$ \\ https://orcid.org/0000-0002-3801-3742 \\ Mykhailo Dumchikov ${ }^{82}$ \\ https://orcid.org/0000-0002-4244-2419 \\ Daria Prokofieva-Yanchylenko ${ }^{83}$ \\ https://orcid.org/0000-0001-6458-5536 \\ Kateryna Yanishevska ${ }^{84}$ \\ https://orcid.org/0000-0002-3648-5543
}

\footnotetext{
${ }^{80} \mathrm{PhD}$ in Law, Senior Lecturer, Department of Criminal Legal Disciplines and Procedure, Sumy State University, Ukraine.

${ }^{81} \mathrm{PhD}$ in Law, Senior Lecturer, Department of Criminal Legal Disciplines and Procedure, Sumy State University, Ukraine.

${ }^{82} \mathrm{PhD}$ in Law, Assistant, Department of Criminal Legal Disciplines and Procedure, Sumy State University, Ukraine.

${ }^{83}$ Doctor of Juridical Sciences, Professor, National Academy of the Security Service of Ukraine.

${ }^{84} \mathrm{PhD}$ in Law, Senior Lecturer, Department of Criminal Legal Disciplines and Procedure, Sumy State University, Ukraine.
} 
conclusion that such dispersion of powers, and in some cases their duplication, does not simplify, but rather complicates the effectiveness of combating corruption.

Key Words: anti-corruption legislation, corruption prevention, anti-corruption actors, financial intelligence. корупції, Національне антикорупційне бюро України, Агенство з розшуку та менеджменту активів, Спеціалізована антикорупційна прокуратура та Вищий Антикорупційний суд України.

Особливу увагу зосереджено на проблемах у співпраці між антикорупційними інституціями. Робиться висновок про те, що усвідомлюючи значущість завдання 3 протидії корупції держава розробила розгалужену та відносно замкнену систему спеціалізованих антикорупційних органів. Поза тим певні стратегічні повноваження у сфері протидії корупції зберегли й органи загальної компетенції.

Ключові слова: антикорупційне законодавство, протидія корупції, суб'єкти протидії корупції, фінансовий моніторинг.

\section{Introduction}

The search for the agreed-upon definition of corruption has been a key element of scientific research on corruption in recent decades, without reaching any consensus in the academic circles. Moreover, citizens are unlikely to have a common understanding of what should be labeled as "corruption" in time, space, and social groups (Wickberg, 2021). We believe that corruption is a negative social and economic phenomenon, which in various amounts is inherent to all countries of the world (Bondarenko, Reznik, Yevgen, Andriichenko, \& Stohova, 2020). Corruption is one of the critical threats to national security as it harms the financial system, negatively affects the public confidence in the state and the ability of government agents to protect national interests through the appropriation of public office intuit personae (Drozd, Nykytiuk, Dorofeieva, Andriiko, Sablu, 2020). Currently fight against corruption is one of the most important tasks facing Ukrainian law enforcement agencies. The future of the state largely depends on success in this struggle (Shcherbakovskyi, Stepaniuk, Kikinchuk, Oderiy, \& Svyrydova, 2020). The indicated task requires agreed efforts and work from all state institutions without exception. In 2014 anti-corruption reform was launched, which radically renewed the system of authorities endowed with competence in the sphere of anti-corruption, outlined the principles of their interaction, and the principal activity directions.

Meanwhile, the Anti-Corruption Policy for 20202024 (Anti-Corruption Strategy) does not shy away from the issue of anti-corruption institutional powers. It provides the optimization of the functions of the state and local selfgovernment, the implementation of which primarily involves: termination of the state and local self-government of superfluous and excessive powers; elimination of powers doubling by different authorities; interim injunction of un-efficient powers implementation, which are characterized by a high level of corruption risks; elimination of implementation cases by the same body of mutually exclusive powers, the combination of which creates additional corruption risks (National Agency for the Prevention of Corruption, 2021).

The importance of the study. It was defined that the functions of some institutions are duplicated.According to this their efficiency in the corruption combating dwindle. Also the place and the role of abovementioned institutions were outlined. The issue on existence expediency of branched system as to anti-corruption institutions.

\section{Research background}

The theoretical basis of the research is academic papers on the institutional features of anticorruption. Thus, A. Lapkin emphasizes that the condition for the successful implementation of state anti-corruption policy is the creation of an appropriate institutional mechanism for the functioning of bodies, authorized to prevent corruption offenses, their establishment and investigation, detection, and government action (Lapkin, 2021). 
O. Novikov is also of the opinion that reforming the legal groundwork of state administration in general and legal support of anti-corruption is one of the ways to reduce corruption in state administration. The topicality of such reforms is confirmed by the recommendations of authoritarian international institutions (Novikov, 2015).

According to I. Kulchiy the reform of public authorities and the formation of anti-corruption institutions should be the result of comprehensive and systematic changes in legislation and quality of work (Kulchiy, 2016).

O. Yarmish and R. Melnyk believe that the need to create specialized anti-corruption authorities arise when structural or organizational shortcomings of existing bodies do not allow them to effectively perform preventive and repressive functions of fighting corruption. Thus, the Ukrainian legislator analyzed the world experience in creation of institutions specifically designed to conduct enhanced the fight against corruption, which combines both preventive and repressive elements (investigation) (Yarmish, Melnik, 2015).

N. Shinkarenko aptly notes that the key component of the issue of institutional support for combating corruption is the dispersion of anti-corruption functions between law enforcement agencies (Shinkarenko, 2016).

\section{Methodology}

The success of the scientific study is directly proportional to the choice of the correct research design, which would be able to ensure the comprehensiveness and completeness of the study, slowed to elaborate conclusions and recommendations that would play a pivotal role for scientific and practical activity. The authors used the phenomenological method, which allowed to extend boundaries of legal discernment, established by traditional ways of law understanding, formed a picture of legal reality. The descriptive method was used to outline certain concepts, phenomena, processes. And in this study, this method was used while qualitative characteristic of the concept of criminal legal counteraction to corruption. The hypothetic-deductive method is a hierarchy of hypotheses, abstraction, and commonality degree of which increases with distance from the empirical basis. The statistical method was used to collect and summarize official information on the fight against corruption in Ukraine. The method of case law analysis involves the case study. This method is of considerable use in the criminal law and criminology doctrine aimed at identifying legal relation regulation and the specifics of law enforcement.

\section{Results and discussion}

The analysis of the scientific literature demonstrates that special anti-corruption authorities that are of special scientific interest are new for the domestic system of public administration. Moreover, the authors are convinced of the need for a defensible analysis of state bodies, which also have certain separate, but strategic powers in the sphere of anti-corruption. In general, a large number of state institutions, which the authors proposed to consider schematically in Figure 1 represents the system of anti-corruption authorities in Ukraine. 


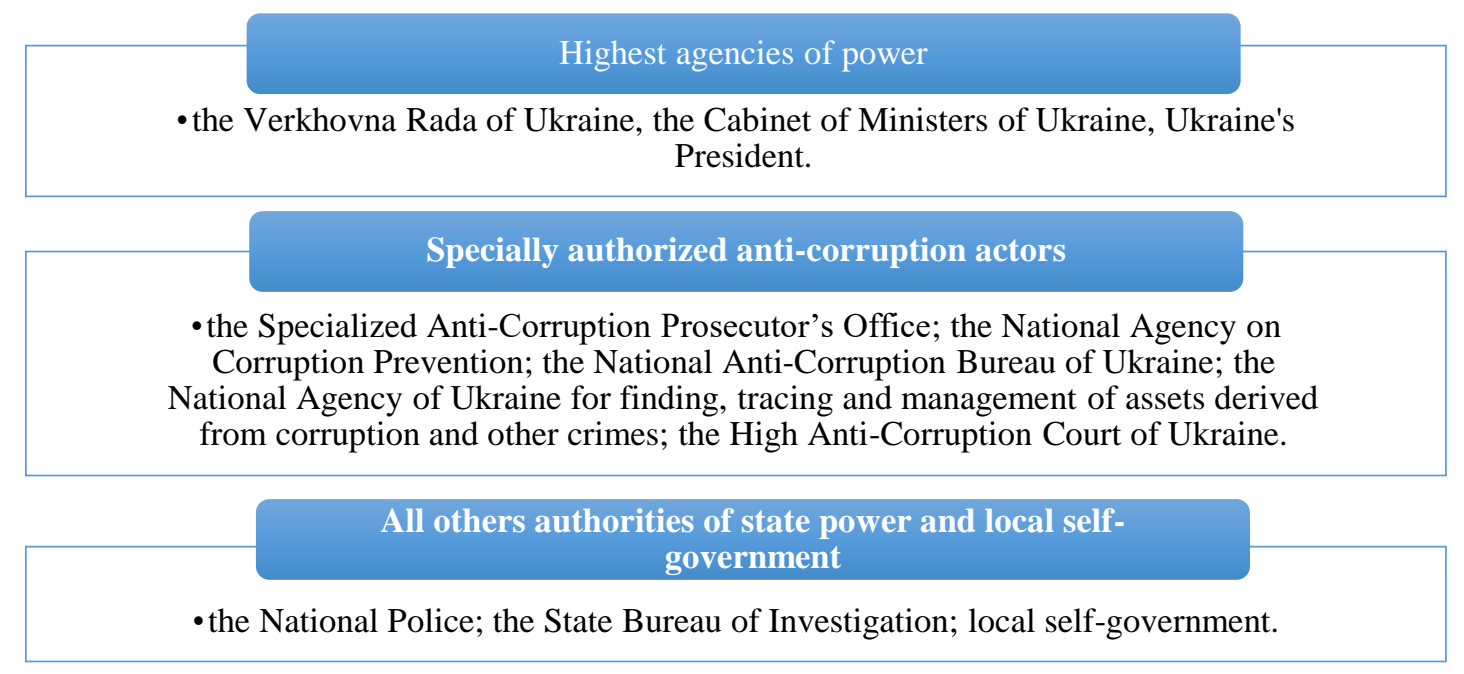

Figure 1. Structure of anti-corruption institutions of ukraine (bondarenko o., utkina m., dumchykov m. et al.)

\section{The Verkhovna Rada of Ukraine as a general competence authority to combat corruption in Ukraine}

Foremost, the authors propose to emphasize the anti-corruption powers of the Verkhovna Rada of Ukraine. According to the Art. 75 of the Constitution of Ukraine, the Verkhovna Rada of Ukraine is the sole body of legislative power in Ukraine (Constitution of Ukraine, 1996). Now therefore it is this state body that determines the vector of anti-corruption in the state, by defining the principles of anti-corruption policy and by ratifying international anti-corruption treaties. Besides, people's deputies of Ukraine, along with other actors of legislative initiative, submit their draft laws for anti-corruption examination, excluding anti-corruption examination of draft regulations submitted to the Verkhovna Rada of Ukraine by people's deputies of Ukraine by the Committee of Verkhovna Rada of Ukraine whose subject is the issue of corruption prevention (Law No. 1700-VII, 2014).

The Anti-Corruption Policy Committee of the Verkhovna Rada of Ukraine indefeasible plays an important role in the anti-corruption activities of the Verkhovna Rada of Ukraine. According to the Art. 11 of the Law of Ukraine "On Committees of the Verkhovna Rada of Ukraine" the main functions of Committees are legislative, organizational, and control (Law No. 116/95VR, 1995).

According to the Resolution of the Verkhovna Rada of Ukraine № 19-IX dated August 29, 2019 "On the list, number and subject of Committees of the Verkhovna Rada of Ukraine of the Ninth
Convocation" there are specific powers of the Anti-Corruption Policy Committee of the Verkhovna Rada of Ukraine as follows: anticorruption policy formation; carrying out anticorruption expert examination of bill drafts submitted by the actors of the right of legislative initiative; corruption prevention and counteraction; corruption prevention while legal entities activity; prevention and settlement of competetive interests; determination of rules of ethical conduct in the public service; financial control over persons authorized to perform the functions of the state and local self-government; determination of the grounds for liability for committing corruption offenses and corruptionrelated offenses; legal regulation and organization of activities of the National AntiCorruption Bureau of Ukraine, the National Agency on Corruption Prevention, the National Agency of Ukraine for finding, tracing and management of assets derived from corruption and other crimes; activities of other law enforcement and state bodies in terms of their powers in the sphere of preventing and combating corruption; formation of the principles of state protection for persons who provide assistance in preventing and combating corruption (Resolution No. 19-IX, 2019).

The committee has eight subcommittees: subcommittee on legal regulation and analysis of the activities of special authorities in the sphere of preventing and combating corruption; subcommittee on compliance with legislation in the sphere of preventing and combating corruption by the state and local selfgovernment; subcommittee on international partnership and cooperation on the 
implementation of anti-corruption policy in the financial, agro-industrial and energy spheres; subcommittee on compliance with anticorruption legislation in the field of defense industry reform; subcommittee on interaction with civil society; subcommittee on anticorruption policy in the sphere of digital innovation and public data; subcommittee on anti-corruption policy in the economic sphere; subcommittee on combating corruption in the sphere of ecology and nature management (Verkhovna Rada Committee on AntiCorruption Policy, 2021).

A systematic analysis of these subcommittees' powers allows authors to conclude that most of the general powers of the committee are scattered among them in the sectoral area, while certain powers are duplicated in the activities of all subcommittees (anti-corruption examination of regulations).

\section{The Cabinet of Ministers of Ukraine as a general competence authority to combat corruption in Ukraine}

According to the Art. 113 of the Constitution of Ukraine, the Cabinet of Ministers of Ukraine is the highest body in the system of bodies of executive power. The Cabinet of Ministers of Ukraine is responsible to the President of Ukraine and the Verkhovna Rada of Ukraine, it under the control of and accountable to the Verkhovna Rada of Ukraine within the limits envisaged in the Articles of the Constitution of Ukraine (Constitution of Ukraine, 1996). The list of anti-corruption powers of this central executive body is set out in the relevant Law and is quite broad. First, per the Constitution of Ukraine and the Law of Ukraine "On Prevention of Corruption" this executive forms the National Agency on Corruption Prevention (Part 3 of Article 4), appoints and dismisses its chairman (Part 1, Part 5 of Article 5 ). Secondly, it approves the maximum number of employees of the staff of the National Agency on Corruption Prevention (Part 2 of Article 8). Third, it determines the procedure for forming the composition of the Public Council at the National Agency on Corruption Prevention and approves the provisions on it (Part 2 of Article 14). Fourth, it approves the composition, criteria, and methodology of the Commission for conducting an independent evaluation of the effectiveness of the National Agency on Corruption Prevention (Part 4, Part 14). Fifth, it approves the state program for the implementation of the anticorruption strategy (Part 4 of Article 18). Sixth, no later than April 15, annually it considers and approves the draft of the national report on the implementation of the anti-corruption policy principles (Part 4 of Article 20). Seventh, it determines the procedure for the transfer of official gifts to the state, territorial community, state or municipal enterprises, institutions, or organizations (Part 3 of Article 23). Eighth, it determines the procedure for conducting a special inspection and the form of acceptance to conduct it by organizations (Part 1 of Article 57). Ninth, it determines the coordination and exchange arrangements between authorities (subdivisions) concerning information about a person, in particular about persons applying for positions in which a state secret is a part (Part 1 of Article 58).

Tenth, it determines the procedure for conducting an internal investigation on the commission of corruption or corruption-related offense or noncompliance with the requirements of the anticorruption law in another way (Part 3 Article 65-1) (Law No. 1700-VII, 2014).

The authors hold that such a significant list of powers is due to the priority status of the Cabinet of Ministers of Ukraine in the structure of central executive bodies and is aimed at broad coordination of the Cabinet of Ministers of Ukraine as anti-corruption activities in general and the National Agency on Corruption Prevention in particular.

\section{Ukraine's President as a general competence authority to combat corruption in Ukraine}

Re the powers of Ukraine's President in the sphere of corruption combating, the head of state is an authority who must ensure the implementation of the strategic task of overcoming corruption to implement Part 3 of Art. 102 of the Basic Law. It provides for full membership of Ukraine in the European Union and the North Atlantic Treaty Organization (Constitution of Ukraine, 1996).

The specific authority of Ukraine's President, which are also outlined in the Law of Ukraine "On Prevention of Corruption" include as follows: submitting a petition to the Verkhovna Rada of Ukraine to dismiss the Minister for Foreign Affairs of Ukraine and the Minister of Defense of Ukraine according to the Part 3 of Art. 22 of the Law (Part 4 of Article 45-1); submits its acts for the annual anti-corruption examination (Part 4 of Article 55). 
A special place in the anti-corruption activities of the head of state is occupied by the National Council for Anti-Corruption Policy, which is an advisory body to Ukraine's President. Key tasks of the National Council for Anti-Corruption Policy are as follows: 1) preparation and submission of proposals to the Ukraine's President on the definition, updating and improvement of anti-corruption strategy; 2) systematic analysis of the conditions on prevention and counteraction to corruption in Ukraine, the effectiveness of the anti-corruption strategy implementation, and measures taken to prevent and combat corruption; 3) preparation and submission to the Ukraine's President of agreed proposals for improving coordination and interaction between authorities implementing measures in the sphere of preventing and combating corruption; 4) assessment of the conditions and promotion of the GRECO recommendations, the Organization for Economic Cooperation and Development (OECD), other leading international organizations on preventing and combating corruption, increasing the effectiveness of international cooperation of Ukraine in this sphere; 5) facilities for scientific and methodological support on the prevention and combating corruption. Decisions of the Council, when required, are implemented by the issuance of acts of Ukraine's President following the established order, submission of relevant bills by the President to the Verkhovna Rada of Ukraine (Decree of the President of Ukraine $N^{\circ} 41,2014$ ).

\section{Specially authorized anti-corruption actors}

Creation of special anti-corruption institutions, the activities of which are aimed at both active countermeasures and prevention of corruption and any of its manifestations is one of the ways to combat corruption in world practice (Novikov, 2015). This idea, enshrined in Art. 36 of the UN Convention against Corruption, which provides for all member countries to the Convention to ensure, following the fundamental principles of their legal system, the presence of a body or bodies or persons specializing in combating corruption through law enforcement activities. Such authority or authorities shall be accorded the necessary autonomy, per the fundamental principles of the legal system of the member country, to enable them to carry out their functions effectively and without any undue influence (United Nations, 2005). A similar requirement is reflected in the Criminal Law Convention on Corruption.
An analysis of international experience shows that some countries have extensive experience in the operation of state specialized bodies for combating corruption. Such states include the Republic of Korea, Singapore, and India. There is an Anti-Corruption and Civil Rights Commission in the Republic of Korea, which reports to the President on the fight against corruption, coordinates anti-corruption policy, improves anti-corruption legislation, carries out international cooperation in preventing corruption, submits relevant reports on the implementation of anti-corruption measures, and performs many other functions (Polyakov, 2019) Corrupt Practices Investigation Bureau functions in the system of state bodies in Singapore. This specialized anti-corruption authority has been operating since 1952, which has made it possible to combat corruption in Singapore's public administration as effectively as possible for many decades. Traditionally, Singapore is one of the countries with the least corrupt public sector.

Anti-corruption government agencies and officials also exist in European countries. In particular, in France it is the Service central de prevention de la corruption (SCPC), in Romania - Direcţia Naţională Anticorupţie (DNA), in Croatia - Ured za suzbijanje korupcije i organiziranog kriminala (USKOK) (Polyakov, 2019)

Thus, given the international obligations of our state, positive international experience, and the need for a complete overload of anti-corruption state institutions after the revolution of dignity, there is an urgent need to create special authorities that would be endowed with exclusive competence in combating corruption (Komirnychy, 2021).

Choosing a specific model of anti-corruption authorities' organization, the domestic legislator decided to create an extensive system of individual public authorities, delimiting their powers. This model was chosen given the scale of corruption in our country and the persistent, deep-seated nature of political corruption (Dulsky, 2012), and as a consequence the importance of an integrated approach. Thus, the Specialized Anti-Corruption Prosecutor's Office; the National Agency on Corruption Prevention; the National Anti-Corruption Bureau of Ukraine; the National Agency of Ukraine for finding, tracing, and management of assets derived from corruption and other crimes; the High Anti-Corruption Court of Ukraine were established in our country. They provide for the investigation of certain corruption offenses. 


\section{The National Agency on Corruption Prevention}

The Cabinet of Ministers of Ukraine established this central executive body with a special status in March 2015. He started his official activity almost a year later (in April 2016), when a minimum number of the National Agency on Corruption Prevention members was appointed, it has been completed recruitment, premises, and material and technical base have been allocated (Sozansky, Lutsyk, 2018).

The National Agency on Corruption Prevention in Ukraine was established as a multi-purpose public authority to implement an integrated approach and concentrate all key anti-corruption functions within a single institution. This model of a multi-purpose anti-corruption agency provides for the implementation of many functions as follows: policy formation, analytical activities, technical assistance, cooperation with civil society, the introduction of public access to information, financial intelligence (Volik, 2016). The Law is the main legally enforceable enactment that establishes the legal basis of activities, rights, responsibilities, and powers of the National Agency on Corruption Prevention in Ukraine. The legal nature of both the National Agency on Corruption Prevention in Ukraine and its members is described in detail. Therefore, for a systematic and simplified presentation of the rights and responsibilities of this authority, the authors propose to consider them in Table 1.

Table 1.

Legal Nature of the Members of the National Agency on Corruption Prevention in Ukraine.

\section{№ Rights of members of the National Agency on Corruption Prevention in Ukraine}

Right to information accessibility: to get

1 acquainted with the documents that are in the National Agency on Corruption Prevention in Ukraine and to make inspections

Right to make proposals: to make a proposal of 2 agenda items of the National Agency on Corruption Prevention in Ukraine within its competence

Right to direct participation in the proceedings: speak at the proceedings of the Agency, to table

3 a proposal, to cause conduction of the poll, to put his/her ideas on paper in case of disagreement of decision

Right to be a representative of the National Agency on Corruption Prevention in Ukraine in relations with public authorities: to participate

4 in the proceedings of the Verkhovna Rada of Ukraine, the Cabinet of Ministers of Ukraine, temporary special and investigative commissions, ministries, and authorities

\section{Responsibilities of members of the National Agency on Corruption Prevention in Ukraine}

Responsibility to take part in proceedings of the National Agency on Corruption Prevention in Ukraine: to prepare issues to consider, attend proceedings, and go to the polls

Responsibility to strictly enforce the National Agency on Corruption Prevention in Ukraine decisions: to provide within the competence of execution of the decision of the National Agency on Corruption Prevention in Ukraine

Responsibility to coordinate work of juniors: exercise the powers and authority and to regulate the work of business and support units of the National Agency on Corruption Prevention in Ukraine according to the defined division of function and authority

Responsibility to be a representative of the National Agency on Corruption Prevention in Ukraine in "external" affairs: to represent the National Agency on Corruption Prevention in Ukraine in relations with authorities, nongovernmental organizations, individuals, and legal entities in Ukraine and abroad (Volik, 2016).
For the analysis of the effectiveness of the National Agency on Corruption Prevention in
Ukraine, the authors analyzed both the achievements and shortfalls. 
Table 2.

Achievements and shortfalls of the National Agency on Corruption Prevention in Ukraine.

\begin{tabular}{|c|c|c|}
\hline № & Achievements & Shortfalls \\
\hline 1. & $\begin{array}{l}\text { The Register of Declarations of Persons Authorized } \\
\text { to Perform the Functions of the State or Local Self- } \\
\text { Government was created (2016). Over the years, } \\
\text { the officials of the National Agency on Corruption } \\
\text { Prevention in Ukraine have shown signs of avowry } \\
\text { inaccurate information in an amount totaling more } \\
\text { than UAH } 17 \text { billion. }\end{array}$ & $\begin{array}{l}\text { The work of the Register was blocked by a } \\
\text { decision of the Constitutional Court of } \\
\text { Ukraine dated by October } 27,2020 \text {, } \\
\text { No. } 13-\text { p/ } 2020 \text {. }\end{array}$ \\
\hline 2. & $\begin{array}{l}\text { The Unified State Register of Persons who Have } \\
\text { Committed Corrupt or Corruption-Related } \\
\text { Offences. }\end{array}$ & $\begin{array}{l}\text { The weakness of filling state registers and } \\
\text { databases. Lack of full transparency, } \\
\text { which is important for the automated } \\
\text { inspection of information, is provided in } \\
\text { the declarations. }\end{array}$ \\
\hline 3. & $\begin{array}{l}\text { The System of Logical and Arithmetic Control of } \\
\text { Declarations has been developed and put into } \\
\text { operation. }\end{array}$ & $\begin{array}{l}\text { The System of Logical and Arithmetic } \\
\text { Control of Declarations was changed due } \\
\text { to the imperfection of the risk criteria, and } \\
\text { as a result, many declarations were } \\
\text { assigned to the "red zone", which required } \\
\text { additional verification. At the same time, } \\
\text { the approved updated criteria remain } \\
\text { ambiguous. }\end{array}$ \\
\hline 4. & $\begin{array}{l}\text { A mechanism of control over the timeliness } \\
\text { of declarations submission was developed and } \\
\text { implemented - from monitoring to service of a } \\
\text { notice by the National Agency in Ukraine to the } \\
\text { actors of anti-corruption declaration and submission } \\
\text { of substantiated reports of the National Agency on } \\
\text { Corruption Prevention in Ukraine to law } \\
\text { enforcement agencies }\end{array}$ & $\begin{array}{l}\text { A mechanism of control is too general, it is } \\
\text { not clearly defined how to prove the } \\
\text { existence of technical problems when } \\
\text { filling out the declaration, but as a } \\
\text { consequence of its late submission. }\end{array}$ \\
\hline 5. & $\begin{array}{l}\text { A feasibility study of the case management system } \\
\text { was developed. This system streamlines the } \\
\text { workflow of the National Agency on Corruption } \\
\text { Prevention in Ukraine structural units provides easy } \\
\text { tracking of all related documents, and prevents } \\
\text { duplication of requirements by different National } \\
\text { Agency on Corruption Prevention in Ukraine } \\
\text { structural units for the object }\end{array}$ & $\begin{array}{l}\text { Lack of guarantees regarding the } \\
\text { impossibility of interfering in the activities } \\
\text { of the case management system, and thus } \\
\text { making changes to the documents. }\end{array}$ \\
\hline
\end{tabular}

Because the National Agency on Corruption Prevention in Ukraine is a relatively new public authority, it certainly takes some time to develop effective mechanisms and set up work. The task of other state institutions, in the presence of these internal obstacles, is to ensure the implementation of political will to implement anti-corruption reforms and ensure the absence of resistance. The authors are convinced of the importance of implementing a systematic and consistent approach to anti-corruption reforms, and thus preventing the recurrence of cases of the abolition of criminal liability for corruption offenses, as was the case with illicit enrichment and declaration of inaccurate information.
The National Agency of Ukraine for finding, tracing and management of assets derived from corruption and other crimes.

The National Agency of Ukraine for finding, tracing, and management of assets derived from corruption and other crimes was created based on the analogy with the institutions for recovery and asset management, which have proven themselves in the EU Member States. The need to create such a narrow body of state power was due to a combination of factors, both external and internal (Asset Search and Asset Management Agency, 2021). The international obligations of our state, outlined in numerous international treaties, have undoubtedly played a key role. In particular, Part 1 of Art. 31 of the United Nations 
Convention against Corruption provides taking all necessary measures by member countries to enable the seizure of the proceeds of crime as defined in this Convention or property whose value corresponds to the value of such income; property, equipment, and other means used or intended for use in the commission of criminal offenses as defined in this Convention (United Nations, 2005). The authors consider it is necessary to note the fundamental role of the Convention on Laundering, Search, Seizure, and Confiscation of the Proceeds from Crime (Strasbourg Convention or CETS), the Action plan on Visa Liberalisation for Ukraine, the binding recommendations of the Organization for Economic Co-operation and Development (OECD) and Directive 2014/42 / EU, in the creation of the National Agency of Ukraine for finding, tracing and management of assets derived from corruption and other crimes in Ukraine.

As for the internal regulations, it is obvious that the fight against criminal corruption offense involves not the only prosecution of corrupt officials, but also eliminating at least some of the material damage caused by them. Thereat, it is important to ensure objectivity, impartiality, professionalism, and integrity in the implementation of measures to identify, search, evaluate assets, as well as their management.

The main purpose of the National Agency of Ukraine for finding, tracing, and management of assets derived from corruption and other crimes in Ukraine follows from its name. It searches for assets, proves them to be criminally illegal or corrupt, confiscates them solely by court order, and can then put them up for sale at public auction. All information about assets and accounts is stored in a specially created open register, which is also maintained by the agency (Made for minds, 2021).

After the transfer of the National Agency of Ukraine for finding, tracing, and management of assets derived from corruption and other crimes in Ukraine assets, for the implementation of administrative measures, the owner does not permanently lose authority over such assets. The Agency will reimburse the funds received from this asset, as well as interest accrued as a fee for the use of these funds by the bank in case of implementation of such acts. In such circumstances, the asset owner loses the opportunity to exercise only certain property rights. Withdrawal of ownership occurs not only per the principles set out by the European Court of Human Rights, but also based on compensation - the owner receives adequate compensation for the relevant asset (property) (Los, 2019). Thus, the activity of the National Agency of Ukraine for finding, tracing, and management assets derived from corruption and other crimes in Ukraine is intended not only to seize property as a measure in criminal proceedings but also guarantees a kind of protection of the interests of the owner, because it involves the preservation of property and its value. Analysis of the Agency activity reports shows a positive trend: the National Agency of Ukraine for finding, tracing, and management of assets derived from corruption and other crimes in Ukraine was found cash for the total amount: in 2018 - UAH 357.7 million, 97.8 million dollars, 1.9 million euros; in 2019 - UAH 876.78 million, 16,59 million dollars, 7,7 million euros; and in 2020-UAH 957,68 million (Asset Search and Asset Management Agency, 2021).

Thus, the authors would like to note the positive vector of the National Agency of Ukraine for finding, tracing, and management of assets derived from corruption and other crimes in Ukraine activity and emphasize that the commissioning of the Unified State Register of Assets Seized in Criminal Proceedings will be another step towards reducing corruption in Ukraine and cooperation between the Office of the Prosecutor General of Ukraine and the National Agency of Ukraine for finding, tracing and management of assets derived from corruption and other crimes in Ukraine, in case of integration of this register into the Unified Register of Pre-trial Investigations.

\section{The National Anti-Corruption Bureau of Ukraine}

The National Anti-Corruption Bureau of Ukraine occupies a decisive place in combating corruption offenses. After all, this law enforcement agency is intended to prevent, detect, stop, investigate and prevent most of the legally defined list of corruption offenses.

The formation of this anti-corruption institution is primarily due to Art. 36 of the United Nations Convention against Corruption (United Nations, 2005). Also, the need to increase the effectiveness of the fight against corruption by reforming institutions that investigate and prosecute corruption offenses has become a prerequisite (Shinkarenko, 2016). 
The authors would like to reiterate that even though the National Anti-Corruption Bureau of Ukraine was established as a special anticorruption agency, the powers of law enforcement agencies to investigate corruption offenses have not been unified. (Grechanyuk, 2015). As a result, the creation of the Bureau did not justify its goal. Duplication of powers of anticorruption bodies also remains problematic, which in turn leads to an increase in public spending. The Law of Ukraine "On the National Anti-Corruption Bureau of Ukraine" also significantly limits the powers of this body. After all, the Bureau can act only as a body to combat so-called high-level corruption. That is why the authors consider it expedient to support R. Grechanyuk's position that the implemented domestic model of an independent anticorruption law enforcement body proved ineffective and it is appropriate to transfer the function of pre-trial investigation of all corruption offenses to the National AntiCorruption Bureau of Ukraine, eliminating it from other law enforcement agencies. Besides, it is important to expand the powers of the National Anti-Corruption Bureau of Ukraine, by extending the competence not only to highranking corruption (Grechanyuk, 2015).

If we analyze the effectiveness of anti-corruption authorities in Ukraine, then, according to a study conducted by the American Chamber of Commerce, the least effective authority in Ukraine is the National Anti-Corruption Bureau of Ukraine (American Chamber of Commerce in Ukraine, 2017).

Such a low assessment of the effectiveness of this public authority is due to the low economic effect, as the National Anti-Corruption Bureau of Ukraine was able to recoup only $0.26 \%$ of the losses incurred by the state. Even though the return of the abducted, appropriated is not the main function of the Bureau, experts are convinced that such unproductiveness indicates a lack of political will, which can inadvertently become hostage to the already formed plexus of influential interests. Under such conditions, declarative brutal anti-corruption activities become absurd. Thus, last year the National AntiCorruption Bureau of Ukraine transferred a total of UAH 158.95 million to the budget from UAH 229.7 billion, which was tentatively calculated by detectives as compensation to the state. And during the whole time of its activity, the National Anti-Corruption Bureau of Ukraine ensured the return of only $0.3 \%$ of this amount - UAH 601.6 million. At the same time, according to the reports of the State Treasury Service, last year alone the National Anti-Corruption Bureau of Ukraine spent much more on staff maintenance than anti-corruption bodies could return for the entire period of its activity - UAH 785.5 million (Lebed, 2021).

Thus, the issue of efficiency and expediency of the existence of such an extensive system of anticorruption authorities remains open. To increase the productivity of the National Anti-Corruption Bureau of Ukraine, it is important to comply with several requirements: expansion of powers, professional selection of personnel, and the absence of political interference in the investigation.

\section{The Specialized Anti-Corruption Prosecutor's Office}

To create a system that would effectively fight corruption in Ukraine, the formation of the functions of a specialized prosecutor's office as a specially authorized anti-corruption authority is of particular importance (Kovalchuk, 2018). The importance of the Specialized Anti-Corruption Prosecutor's Office in the vertical of anticorruption authorities of our state is reduced to the performance of general functions of the prosecutor's office, but only in criminal proceedings for corruption offenses. This is evidenced by Part 5 of Art. 8 of the Law of Ukraine "On the Prosecutor's Office" and Section 3 of the Regulation on the Specialized Anti-Corruption Prosecutor's Office of the Prosecutor General, approved by the order of the Prosecutor General № 12505 March 2020. According to it, the Specialized Anti-Corruption Prosecutor's Office is entrusted with the following tasks and functions: 1) supervisory action the law compliance during operational and investigative activities, pre-trial investigation of the National Anti-Corruption Bureau of Ukraine; 2) support for public prosecution in relevant proceedings; 3 ) representation of the interests of a citizen or the state in court in cases provided by law and related to corruption offenses (Resolution № 125, 2020). The reason for the creation of such a specialized authority was, already mentioned, Art. 36 of the United Nations Convention against Corruption and the experience of similar bodies in foreign countries. In particular, in Spain, there is the State Prosecution Service for Combating Corruption and Organized Crime, which is an autonomous authority and is designed to provide procedural guidance for investigating and supporting public prosecutions for corruption. A similar authority operates in the Romanian prosecutor's office - the National Anti-Corruption Directorate. The 
purpose of this authority is the criminal prosecution of corruption crimes, medium and high level (Pronevych, 2015).

The main problematic issues regarding the activities of the Specialized Anti-Corruption Prosecutor's Office arise in connection with the separation of functions with the Office of the Prosecutor General. Especially in the field of international cooperation because this area is of particular interest to ensure the proper functioning of the Specialized Anti-Corruption Prosecutor's Office. The importance of international cooperation is due to the enormous importance of the international community, including the EU, for initiating anti-corruption reforms in Ukraine. The Specialized AntiCorruption Prosecutor's Office must ensure proper supervision of compliance with anticorruption legislation on the one hand and prevent violations of citizens' rights on the other. However, there are constant questions about the limits of the autonomy of the Specialized AntiCorruption Prosecutor's Office in the structure of the Office of the Prosecutor General.

The Specialized Anti-Corruption Prosecutor's Office is an important actor of the mechanism of realization of the state anti-corruption policy in the aspect of the investigation of corruption criminal offenses, bringing to the criminal responsibility of the persons guilty of their commission and compensation of the caused to the state, their commission, damage.

It should perform the functions of the Prosecutor's Office concerning the National Anti-Corruption Bureau of Ukraine as an authority of pre-trial investigation and operational and investigative activities, as well as assist the Specialized Anti-Corruption Prosecutor's Office is considering and resolving cases of corruption offenses. (Lapkin, 2021).

\section{The High Anti-Corruption Court of Ukraine}

The High Anti-Corruption Court of Ukraine is one of the newest anti-corruption authorities in Ukraine. Thus, on June 7, 2018, the Law of Ukraine "On the High Anti-Corruption Court" was adopted. The anti-corruption court should be the last link in the chain of newly created anticorruption authorities that will be able to ensure the inevitable punishment of corrupt officials. Unavoidability of punishment and fair sanctions for the criminal infraction will have a real impact on reducing corruption in Ukraine (Kostecki, 2021). The goal of the High Anti-Corruption
Court of Ukraine is the effectuation of fair, objective, and impartial justice for corruption offenses. Under this goal, the Law of Ukraine "On the High Anti-Corruption Court" defines the main tasks of the High Anti-Corruption Court: 1) effectuation of justice following the principles and procedures established by law to protect individuals, society, and the state from corruption and related criminal offenses and judicial control over the pre-trial investigation of these criminal offenses; 2) observance of the rights, freedoms, and interests of persons in criminal proceedings; 3 ) resolving the issue of recognizing unfounded assets and their recovery into state revenue in cases provided by law, in civil proceedings (Law No. 2447-VIII, 2018).

The need to create it today is a very controversial issue. Society is divided into two camps: those who support the creation of a specialized court, and those who oppose its formation. Both sides have put forward strong arguments to confirm their position, but the usefulness of creating another anti-corruption body can be said only after the first productive steps in the fight against corruption (Prokopiv, 2018). Skepticism about the effectiveness of the High Anti-Corruption Court is also because the existing anti-corruption authorities (the National Agency on Corruption Prevention; the National Anti-Corruption Bureau of Ukraine; the Specialized Anti-Corruption Prosecutor's Office) missed expectations of both the international community and domestic civil society.

For example, the authors would like to emphasize that before the establishment of the specialized court, all cases concerning acts under investigation by the National Anti-Corruption Bureau of Ukraine were considered by local courts, which is four years managed to pass only thirty-three decisions. Most of them were based on plea agreements between the Specialized Anti-Corruption Prosecutor's Office prosecutors and defendants. As for the activities of the Specialized Anti-Corruption Prosecutor's Office itself, from September 5, 2019, to the end of 2020, 21 decisions were passed. 20 of them were guilty, and 1 - acquittal. 7 persons were prosecuted for actions that consisted of receiving, providing, offering, or promising improper advantage; 5 - for abuse of influence, 5 - for declaring unreliable information, 2 - for abuse of office, and 1 - for misappropriation of property (Novikov, 2020).

Thus, it is too early to talk about the real results of this authority. Besides, the authors would like 
to emphasize that they directly depend on the objectivity and efficiency of the bodies that provide a pre-trial investigation of corruption offenses and procedural management.

\section{Cooperation between anti-corruption authorities}

The implementation of such a broad system of specialized anti-corruption authorities has led to certain implementation shortcomings and raised certain questions about their feasibility. First, as A. Savchenko and O. Klimenko aptly remark, regarding their competence. After all, it remains unclear why some authorities only prevent corruption, while others only fight it (Savchenko, Klimenko, 2015). Second, such a broad system of anti-corruption authorities has led to conflicts over the separation of powers and conditions for cooperation between them. The analysis of memoranda of cooperation, joint orders of specialized anti-corruption authorities clearly shows: 1) lack of complexity in the interaction of competent authorities, there is only cooperation on certain issues, such as information exchange; 2) all analyzed documents contain only general provisions on cooperation, without a description of certain procedural aspects, deadlines, obligations of the parties, as well as issues of their responsibility for non-compliance with the agreements; 3 ) there are no mechanisms for assessing the productivity of cooperation, and therefore there is no control (Demyanchuk, $2018)$; 4) there is no necessary coordination in combating corruption offenses.

Such uncertainty has caused many scandals between the specially authorized bodies in the sphere of anti-corruption. For example, on September 19, 2018, the head of the Specialized Anti-Corruption Prosecutor's Office, N. Kholodnytsky, announced that his bodyguards had found a device that had allegedly been installed to eavesdrop on the prosecutor's office building. Later, officers of the Special Operations Department of the National AntiCorruption Bureau of Ukraine arrived at the scene and, according to N. Kholodnytsky, beat his driver.

The National Anti-Corruption Bureau of Ukraine itself said that they did not intend to listen to the head of the Specialized Anti-Corruption Prosecutor's Office. At the same time, the Prosecutor General of Ukraine confirmed that he had authorized the wiretapping of the Specialized Anti-Corruption Prosecutor's Office building (Word and deed, 2021).
Later, in 2020, a new stage of division of powers between the Office of the Prosecutor General and the Specialized Anti-Corruption Prosecutor's Office began. Prosecutor General I. Venediktova stated that, in her opinion, the Specialized AntiCorruption Prosecutor's Office functioned extremely carelessly. She noted that the Specialized Anti-Corruption Prosecutor's Office investigators had failed to complete several highprofile cases for which the perpetrators had not been punished and that the state had not been compensated for millions of damages. I. Venediktova made all her statements on video for a few minutes, concluding that the work of the Specialized Anti-Corruption Prosecutor's Office can be considered not only unworthy but frankly shameful (Anti-corruptionists swear, 2021). Also, the process of pre-trial investigation will suffer from the lack of coordination of officials working in specialized anti-corruption bodies, as proper cooperation of these institutions in the investigation of criminal proceedings is an important aspect of their work and is designed to ensure completeness, objectivity, efficiency, the pre-trial investigation, the appropriateness, and admissibility of the process of gathering evidence and bringing the perpetrators to justice for committing corruption offenses (Mulyar, Khovpun, 2019).

To prevent such situations, to prevent the emergence of new ones, and to form a proper basis for the performance of all tasks of criminal proceedings, it is extremely important to clearly define the limits and scope of specific powers that can be delegated to specialized anticorruption bodies. First of all, we are talking about a clear delineation of several key functions - law enforcement, human rights, lawmaking.

Extremely difficult long-term tasks for specialized anti-corruption bodies are 1) development and approval of a clear system of supervision and control over the activities of specialized anti-corruption bodies. This system must be implemented at least three levels: internal (due to the existence of internal security / internal control units); foreign policy and the public; 2) building strong cooperation between specialized anti-corruption bodies, both among themselves and between other law enforcement agencies (joint training, issuing joint orders that will contain clear algorithms for cooperation, reducing bureaucracy in the exchange of information, etc.) (Savchenko, Klimenko, 2015).

We are convinced that the dispersion of powers, the slow pace of recruitment, special inspections, and certification of employees create even more 
obstacles to reducing the level of corruption in Ukraine, which is already happening at a fairly slow pace. That is why it is very important to coordinate and coordinate the activities of all bodies of special competence in the field of anticorruption, by strengthening and simplifying information exchange within the competence of the National Anti-Corruption Bureau of Ukraine, the National Agency on Corruption Prevention, and the National Agency of Ukraine for finding, tracing and management of assets derived from corruption and other crimes. As well as deepening the cooperation of the Specialized Anti-Corruption Prosecutor's Office with other anti-corruption bodies to form databases of persons who have committed corruption or corruption-related offenses (ParkhomenkoKutsevil, 2019).

Besides, it is very important to show citizens the real results of such public authorities. After all, the level of trust in them according to the results of sociological research is critical, which is shown schematically. Thus, distrust of the Specialized Anti-Corruption Prosecutor's Office is $66 \%$, the National Anti-Corruption Bureau of Ukraine - 65\%, the National Agency on Corruption Prevention - 65\%, and the High AntiCorruption Court of Ukraine - 64\% (Reasoning Center, 2021).

\section{Conclusions}

Thus, realizing the importance of the task of combating corruption, the state has developed an extensive and relatively closed system of specialized anti-corruption bodies (the National Agency on Corruption Prevention, the National Anti-Corruption Bureau of Ukraine, the Specialized Anti-Corruption Prosecutor's Office, the High Anti-Corruption Court of Ukraine). Also, certain strategic powers in the field of anticorruption have been retained by bodies of general competence (the Verkhovna Rada of Ukraine, the President of Ukraine, the Cabinet of Ministers of Ukraine). Moreover, almost all bodies of state power and local self-government have acquired certain anti-corruption competencies. We are convinced that such dispersion of powers, and in some cases their duplication, does not simplify, but rather complicates the effectiveness of combating corruption. Therefore, it will be expedient to use not a quantitative but a qualitative model of formation of anti-corruption institutions, as well as a real and balanced separation of functions and determine the principles of cooperation between them.

\section{Bibliographic references}

American Chamber of Commerce in Ukraine (2017). Recovered from publications https://chamber.ua/ua/

Anti-corruptionists swear (2021). Ukrainska pravda. Recovered from https://www.pravda.com.ua/rus/news/2020/05/2 7/7253356/

Bondarenko, O., Reznik, O., Yevgen, G., Andriichenko, N., \& Stohova, O. (2020). Participation of Ukraine in International Cooperation against Corruption. Amazonia Investiga, 9 (29), 407-416. https://doi.org/10.34069/AI/2020.29.05.45

Constitution of Ukraine (1996) as of January 1. 2021. The Verkhovna Rada of Ukraine. Kharkiv: Pravo, 2020. 82 p. Recovered from https://rm.coe.int/constitution-of-

ukraine/168071f58b

Decree of the President of Ukraine No 41, S. 39. Regulations on the National Council on AntiCorruption Policy: Official Gazette of the President of Ukraine, Art. 1736, 2014 https://www.president.gov.ua/documents/20720 20-34013

Demyanchuk, V.A. (2018). Ways to improve the level of interaction between the subjects of preventing and combating corruption in Ukraine. Legal Journal of Donbass, 1 (62). 97-102.

Drozd, O., Nykytiuk, Y., Dorofeieva, L., Andriiko, O., \& Sabluk, S. (2020). High AntiCorruption Court of Ukraine: the peculiarities of establishment and the first results. Amazonia Investiga, $\quad 9(29)$, 170-178. https://doi.org/10.34069/AI/2020.29.05.20

Dulsky, O. (2012). Foreign experience on institutional ensuring of anti-coruuption. Reality and opportunities of it's implementation in Ukraine. Fight against organized criminality and corruption (theory and practice). 1 (27), 108-116. Recovered form http://www.irbisnbuv.gov.ua/cgi-

bin/irbis_nbuv/cgiirbis_64.exe?C21COM=2\&I2 $1 \mathrm{DBN}=\mathrm{UJRN} \& \mathrm{P} 21 \mathrm{DBN}=\mathrm{UJRN} \& Z 21 \mathrm{ID}=\& \mathrm{IM}$ AGE_FILE_DOWNLOAD=1\&Image_file_nam e=PDF/boz_2012_1_14.pdf

Grechanyuk, R. (2015). Functions and powers of special anti-corruption bodies of Ukraine, Poland and Moldova: a comparative analysis. Scientific journal of the National Academy of the Prosecutor's Office of Ukraine, 2. 41-48.

Komirnychy, P. O. (2021). Legal characteristics of the new anti-corruption legislation. ONG. Recovered from: http://anticorruption.com.ua/pravovaharakteristika-novogo-antikorupcynogo- 
zakonodavstva-ukrayini-ta-stvorenih-na-yogozasadah-antikorupcynih-organv.html

Kostecki, M. (2021). Why anti-corruption courts are important. Media-DK publishing house LLC. Recovered from https://biz.nv.ua/ukr/ experts/kostetskyy_m/chomu-ekonomichnovazhlivo-mati-antikoruptsijni-sudi-

2008723.html.

Kovalchuk, I. S. (September, 2018). Powers of the Specialized Anti-Corruption Prosecutor's Office as a separate structural unit in the system of prosecutor's offices. "Creative path of a scientist: to the 80th anniversary of Professor VV Dolezhan": mater. round. table. resp. ed. NM Bakayanova; compiled by: IO Kislitsyna, MO Demenchuk, SI Yelenych; MES of Ukraine, NU "OYUA". Odessa: Legal Literature.

Kulchiy I. (2016). Reform of the authorities of the sovereign power of Ukraine in the minds of the implementation of anti-corruption policy. State and region, No. 1 (53). 16-20. Recovered from

http://reposit.pntu.edu.ua/handle/PoltNTU/295

Lapkin, A.V. (2021). Specialized anti-corruption prosecutor's office in the mechanism of realization of the state anti-corruption policy. Recovered from https://dspace.nlu.edu.ua/bitstream/123456789/1 2464/1/Lapkin_259-262.pdf

Law No. 116/95-VR. On Committees of the Verkhovna Rada of Ukraine, Information of the Verkhovna Rada of Ukraine, Ukraine, April 4, 1995. Recovered from https://zakon.rada.gov.ua/laws/show/116/95$\%$ E2\%F0\#Text

Law No. 2447-VIII. On the Supreme AntiCorruption Court (2018). Official Gazette of Ukraine, Ukraine, June 7, 2018. Recovered from https://zakon.rada.gov.ua/laws/show/244719\#Text

Law No. 1700-VII. On Prevention of Corruption. Information of the Verkhovna Rada of Ukraine, Ukraine, October 14, 2014. Recovered from https://zakon.rada.gov.ua/laws/show/1700-18

Lebed, N. (2021). Why Ukrainian anticorruption agencies squabble among themselves?. 112 UA International. Website. Recovered from https://112.international/ukraine-top-news/whyukrainian-anti-corruption-agencies-squabbleamong-themselves-51867.html

Los, A. (2019). Analysis of the legislation of the European Union member states in the context of management of seized assets and work of similar bodies of ARMA. Asset management as a function of ARMA: the ratio of law, $\mathrm{N}^{\circ} 1,10-19$. Recovered from https://drive.google.com/file/d/1XHmKFxJZsLi AY4v5WU6G62GyDJHPUg56/view
Made for minds. (2021). What bodies in Ukraine are fighting corruption Recovered from https://www.dw.com/uk/\%D0\%B3\%D0\%BE\% D0\%BB\%D0\%BE\%D0\%B2\%D0\%BD\%D0\%B 0/s-9874.

Mission (2021). Asset Search and Asset Management Agency. Recovered from https://arma.gov.ua/mission

Mulyar, G., \& Khovpun, O. (2019). Interaction of anti-corruption bodies of Ukraine during the investigation of criminal proceedings. Bulletin of the APSVT, 5. 56-65.

National Agency for the Prevention of Corruption (2021). Anti-corruption strategy for 2020-2024. Recovered from https://nazk.gov.ua/wpcontent/uploads/2020/06/NAZK-

Antykoruptsijna-strategiya-23.06.2020.pdf

Novikov, O. (2020). Anniversary of WACS: what the anti-corruption court managed to do. Word and deed. Recovered from https://www.slovoidilo.ua/2020/09/08/kolonka/ oleh-novykov/polityka/richnycya-roboty-vaksvstyh-zrobyty-antykorupczijnyj-sud Novikov, O.V. (2015). World experience of functioning of specialized anti-corruption bodies. Efficiency of public administration, 43, 52-57.

Parkhomenko-Kutsevil, O. I. (2019). Formation and development of modern anti-corruption bodies of state power as a basis for preventing and overcoming corruption: theoretical and methodological analysis: monograph. Kyiv: SE "Ed. House "Staff".

Polyakov, M. M. (2019). Specialized anticorruption bodies of state power and officials in Russia and foreign countries. Journal of their university. IO Kutifina, №. 6, 158-164.

Prokopiv, B. (2018). Specifics of the functioning of the Supreme Anti-Corruption Court in Ukraine: international experience and Ukrainian realities. Actual problems of jurisprudence, $\mathrm{N}^{\mathrm{o}} 3$, 103-107.

Pronevych, O. S. (2015). Institute of Specialized Anti-Corruption Prosecutor's Office in the European State and Legal Tradition. Law Forum, № 1. 261-268.

Reasoning Center (2021). Citizens' assessment of the situation in the country, the level of trust in the executive and law enforcement agencies, the assessment of the Government's activities. Recovered from https://razumkov.org.ua/napriamky/sotsiologich ni-doslidzhennia/otsinka-gromadianamysytuatsii-v-kraini-riven-doviry-dovykonavchykh-ta-pravookhoronnykh-organivvlady-otsinka-diialnosti-uriadu-liutyi-2020r Resolution No. 19-IX. On the list, quantitative composition and subjects of the committees of 


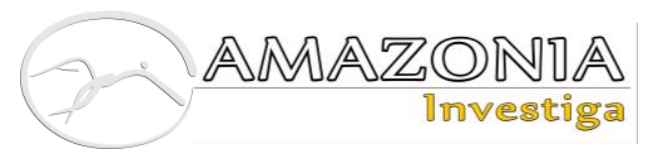

the Verkhovna Rada of Ukraine of the ninth convocation. Information of the Verkhovna Rada, Ukraine, July 29, 2019. Recovered from https://zakon.rada.gov.ua/laws/show/19-

20\#Text

Resolution № 125. On the approval of the Regulation of the Specialized Anti-Corruption Prosecutor's Office of the Office of the Attorney General of the Nation Office of the Attorney General of the Nation, March 5, 2020. Retrieved from https://zakon.rada.gov.ua/laws/show / v0125905-20 \# Text

Savchenko, A., \& Klimenko, O. (2015). Issues of the national model of special anti-corruption bodies. Scientific Journal of the National Academy of the Prosecutor's Office of Ukraine, 4, 136-146.

Shcherbakovskyi, M., Stepaniuk, R., Kikinchuk, V., Oderiy, O., \& Svyrydova, L. (2020). Evidentiary problems in the investigation of corruption crimes in Ukraine. Amazonia Investiga, $\quad 9(32), \quad 117-124$. https://doi.org/10.34069/AI/2020.32.08.12

Shinkarenko, N. V. (2016). National AntiCorruption Bureau of Ukraine as a subject of corruption prevention. Prykarpattya Legal Bulletin, 2, 74-77.

Sozansky, T.I. \& Lutsyk, V. V. (2018). Powers of the National Agency for Prevention of Corruption. Scientific Bulletin of Lviv State University of Internal Affairs, 1, 302-314.

United Nations (2005). United Nations Convention against Corruption. Recovered from
https://www.unodc.org/documents/brussels/UN _Convention_Against_Corruption.pdf

Verkhovna Rada Committee on Anti-Corruption Policy (2021). Subjects of subcommittees. Recovered from http://crimecor.rada.gov.ua/news/Pro_komitet/p redv/73054.html

Volik, V. S. (2016). Regulatory bases of competencies of the National Agency for Prevention of Corruption. Democratic Governance, Vol. 16-17. Recovered from http://nbuv.gov.ua/UJRN/DeVr_2016_16-17_8 Wickberg, S. (2021). Understanding corruption in the twenty-first century: towards a new constructivist research agenda. French Politics, Vol. 19(1), 82-102. https://doi.org/10.1057/s41253-020-00144-4

Word and deed. (2021). The GBR has completed an investigation into an episode near the SAP: NABU employees are suspected. Recovered from

https://ru.slovoidilo.ua/2019/08/13/novost/pravo /gbr-zavershilo-rassledovat-epizod-vblizi-sappodozrevayut-rabotnikov-nabu (access date 21.01.2021).

Yarmish O., \& Melnik R. (2015). Specialized Anti-Corruption Institutions: World Experience and National Model. Scientific Journal of the National Academy of the Prosecutor's Office of Ukraine, $\mathrm{N}^{\mathrm{o}} 2$. 144-155. Recovered from chrome-

extension://oemmndcbldboiebfnladdacbdfmada $\mathrm{dm} / \mathrm{http}$ ://chasopysnapu.gp.gov.ua/chasopys/ua/ pdf/6-2015/yarmysh.pdf 